\title{
THE NATURE OF WORK AND ROLES OF PUBLIC SCHOOL ADAPTED PHYSICAL EDUCATORS IN THE UNITED STATES
}

\author{
Martin Kudláček \\ Ondřej Ješina \\ Dana Stěrbová \\ Faculty of Physical Culture, Palacký University, Olomouc, Czech Republic \\ Claudine Sherrill \\ Department of Kinesiology, Texas Woman's University, Denton, Texas, USA
}

\begin{abstract}
The purpose of this study was to describe the nature of work and roles of public school adapted physical educators in selected school districts in the United States. The greatest significance of this study was the creation of information base to guide improvement of service delivery and professional preparation. Participants of the study were 6 females and 2 males with experience teaching (range of 223 years) in the field of adapted physical education (APE). Data collection included individual indepths interviews, demographic data sheets and interview notes. Results showed the differences in the nature of work among APE specialists. Participants had high teaching loads (44-90 students) and served wide range of schools (1-20), which created quite different teaching profiles. Most teachers were involved in APE consulting. Results also indicated the needs to incorporate issues of consulting into teacher preparation and change the university studies more relevant to "real life teaching".
\end{abstract}

\section{INTRODUCTION}

International studies (Kudláček, Válková, Sherrill, Myers \& French, 2002; Lienert, Sherrill \& Myers, 2001; Meegan \& MacPhail, 2006) tell us that with a growing number of students with disabilities being included in general education, more and more physical education teachers are faced with the reality of teaching these students together with the rest of the children. In most cases teachers are not permitted to decide if they will have a student with a disability in their class, but they can decide to which extent they will include this student (Lienert et al., 2001). There is a great difference between dumping children with disabilities without proper support into general programs and including them in education with other children (Block, 1994; Sherrill, 1998). According to Sherrill (1998, p. 107), "The practice of assigning almost everyone to regular physical education and assuming that teachers will take the initiative in adapting instruction is widespread." With a growing number of students with disabilities being included in general education, more and more physical educators will be faced with the reality of teaching these students together with the rest of the children.

The process of educating children together has had many titles in past starting with mainstream, changing into integration and finally arriving to current title of INCLUSION. Inclusion means providing students with appropriate support and assistance as need to ensure success. Inclusion means that the student with disability is part of the classroom and not an outsider. The student is thus included in activities, and activities are adapted to assure participation. The term "inclusion" is almost universally accepted in English terminology, but in some countries different terms (e.g. integration) are still used preferably. Recently Block and Obrusníková (2007) presented an extensive review of literature done on the topic of inclusion in physical education from 1995 till 2005 and criticized limited numbers and quality of published studies. To understand the nature of inclusion and service delivery in adapted 
physical education is crucial for the improvements of inclusive physical education.

In order to understand perception of inclusion by physical educators LaMaster, Gall, Kinchin, and Siedentop (1998) interviewed 6 elementary school PE specialists, who had students with disabilities in their class. They concluded that teachers were constantly struggling to provide appropriate teaching. Teachers also stated that they felt like they were inadequately prepared to teach effectively in integrated classes. Last issue was little or no support from school in including students with disabilities. Lienert et al. (2001) focused on the experiences and perceptions of physical educators from the USA and Germany. Teachers had personal concerns about uncertainty and worry about everyday demands and their competence to meet these demands. In managerial concerns teachers were worried about lack of resources, large class sizes and inadequate facilities. Teaching was also reported to be much more difficult in an inclusive setting. Finally teacher held collaboration concerns about support and team teaching with other professionals or support personnel.

Lieberman, Houston-Wilson and Kozub (2002) studied perceptions of teachers about barriers to inclusion students with visual impairment in general physical education. Professional preparation, equipment, programming, and time were the most common perceived barriers to inclusion. Morley, Bailey, Tan and Cooke (2005) belong to few Europe based studies. They have focused on perceptions (views) of forty three teachers on inclusion and found the main concern to be about the level of participation. Teachers were concerned with the lack of support services and training and also about the accessibility of environment. Learning more about teachers concerns, perspectives and experiences with inclusive physical education can help with policy and decision making related to school rules and curriculum guidelines. Teachers can also feel like their voice is being heard and finally this information can be used for teacher preparation programs. Common theme of reviewed studies is perceived lack of competence and the lack of support resources.

However support services are available in some countries, states and school districts. Kelly and Gansender (1998) have pointed out that adapted physical educators can provide both direct and indirect services, while direct services mean direct teaching of children with disabilities and indirect service means providing support to teachers attempting to include children with disabilities in their general physical education. Sherrill (1998) emphasized the importance of informing administrators and parents about the benefits of building an adapted physical activity (APA) consultant-coordinator into the budget of school district. From few published studies we know very little about the nature of work of adapted physical educators, their experiences and concerns related to providing support to inclusion. Kelly and Gansender (1998) analyzed job demographics and preparation of 293 APE teachers. This study showed that 59\% of APE specialists provided indirect teaching by support to general physical educators. Indirect services were identified by Kelly and Gansender (1998, p. 146) as: "itinerant or consultant ... providing information, assessment or other assistance..." Two of the main concerns resulting form the study were: (a) caseloads of APE professionals, which were questioned to be too high to meet students' unique needs; and (b) the lack of continuum placements mandated by law in many schools. This study provided important insights into the state of APE in United States of America. The study of Lytle and Hutchinson (2004), which focused on the nature of work of APE consultants in California, also served as guidelines for present study. Lytle and Hutchinson (2004) used phenomenological approach in their study and found multiple roles of APE consultants. Apart from being educators, who share their expertise with PE teachers, assistants or parents, APE consultants are also: advocates, supporters, couriers or important information and resource coordinators. One of 
many selected tasks of APE consultants of APE consultants can be bringing wheelchair basketball team to school, helping PE teachers with acquiring adapted equipment, advocating for specific technological support of student at the IEP meeting, or providing disability awareness programs. It is important to discover how the study can be replicated in Europe or elsewhere and how these findings might influence curriculum and pedagogical approaches for adapted physical education teacher training programs.

All studies published on the nature of work are from the USA. Still we believe that in there is a difference in the nature of service delivery, quality and level of APE in different states. State educational agencies provide educational leadership and they are also setting up state standards for adapted physical education. The right for free appropriate education is mandated by federal law, states usually provide and enforce standards and endorse teaching credentials, but local educational agencies are making decisions about the quality of service provided to all children. Therefore it is important to analyze adapted physical education service in a school district.

The purpose of this study was to describe the nature of work and roles of public school adapted physical educators in selected school districts in the United States. The greatest significance of this study is creation of information base to guide improvement of service delivery and professional preparation. Therefore it is important to study adapted physical education as it functions in different school districts. Detailed description and its critical analysis can be used for refining professional APE preparation and for service delivery at all levels.

\section{METHODOLOGY}

Data collection included individual in-depths interviews, demographic data sheets and interview notes. Triangulation of data was used with in-depth interviews being the main tool, supported by demographic data sheets and interview notes. Trustworthiness of study was established by triangulation of data, member checking for the accuracy of interpretations, and meetings with peer debriefer during the study in accordance with recommendations of Lytle and Hutchinson (2004).

\section{Participants}

Participants of the study were 6 females and 2 males with experience teaching (range of 2-23 years) in the field of adapted physical education (APE). The sampling design of this study was purposive sampling. The use of these criteria is to purposively select participants who are representative of particular population (Sherrill \& O'Connor, 1999). Criteria for the selection of participants were: (a) at least two years of teaching experience in the area of APE in school districts in California or Texas respectively; (b) current employment in the job of APE specialist in school district in California or Texas for at least 20 hours per week; (c) university education in the APE specialization; and (d) willingness to take part in the study. Demographic Data Sheet facts revealed descriptive information about the nature of jobs of APE specialists. Five APE specialists from California had teaching experiences of 14, 19, 18, 23, and 19 years while three APE specialists from Texas had 2, 4 and 8 years of teaching experience. The number of schools served ranged from one to 20 and the number of APE teachers employed in school districts ranged from two to 175 . From this short account we can see that the sizes of school districts and roles of APE specialists differed and thus participants in our study represented school districts with wide variety of conditions for APE. 
Table 1

Demographic Data of Study Participants

\begin{tabular}{|l|l|l|l|l|l|l|}
\hline State & Sex & $\begin{array}{l}\text { Years of Teaching } \\
\text { Experience }\end{array}$ & $\begin{array}{l}\text { Schools } \\
\text { Served }\end{array}$ & Caseload & $\begin{array}{l}\text { \# of APE teachers } \\
\text { Fulltime (part time) }\end{array}$ & $\begin{array}{l}\text { \# of hours } \\
\text { employed for }\end{array}$ \\
\hline CA & F & 19 & 4 & 90 & 175 & 30 \\
\hline CA & F & 19 & 20 & 44 & 4 & 30 \\
\hline CA & F & 18 & 1 & 60 & 6 & 32.5 \\
\hline CA & F & 14 & 8 & 54 & 3 & 37.5 \\
\hline CA & M & 23 & 10 & 48 & $2(0.5)$ & 40 \\
\hline TX & F & 2 & 8 & 90 & 2 & 40 \\
\hline TX & F & 4 & 5 & 55 & $2(4)$ & 40 \\
\hline TX & M & 8 & 5 & 58 & $4(2)$ & 40 \\
\hline
\end{tabular}

\section{Data Collection}

Interviews. Data were gathered through indepth semi structured interview. The approximate length of one interview was around 30 minutes. The interviews were conducted at places available in convention centers during AAHPERD convention. In all cases it was quiet place where no one can interrupt the interview. Before the interview, the participants were asked to sign a consent form and were informed that they could terminate the interview at any time. Participants were sent a copy of their interview transcript and were asked to make corrections or additions if deem necessary (Anastas \& MacDonald, 1994). The in-depth interviews were guided by the findings of study of Lytle and Hutchinson (2004) and were based on a phenomenological theory (Patton, 2002; Strauss \& Corbin, 1990). The selection of interview questions was based on Sherrill (1998), Kelly and Gansender (1998), Block and Conatser (1999). We have focused on the size and appropriateness of caseloads based on findings of Kelly and Gansender (1998), who found that average APE teacher served 4.4 schools and had an average caseload of 104 students. They suggested that this caseload is too large in order to provide appropriate services to all students with disabilities. Block and Conatser (1999) suggested the lack of time as one of three major barriers to APE consulting. Heikinaro-Johanson, Sherrill, French and Huuhka (1995) supported the importance of consulting in physical education as crucial support service for general PE teachers. I suspect that most of the APE professionals have too large caseload and therefore can not successfully serve all students who should be served. Following Lytle and Hutchinson (2004), Sherrill (1998), Block and Conatser (1999) emphasis of the importance of APE consulting, we have focused part of our interview on consulting process. Kelly and Gansender (1998) suggested that the role of adapted physical educators in the decision making process is limited and therefore we have focused on the role in decision making.

Demographic Data Sheet Included questions about personal background, job demographics and demographics of school district. These data will serve to better identify the school districts' conditions, job roles, and background information about APE teacher. Data will be used in combination with interview questions to better understand job roles of physical educators. Themes for both kinds of questions were derived from Sherrill (1998), Kelly and Gansender (1998), Block and Conatser (1999). 


\section{Data Analysis}

Data were recorded, reduced, organized, and analyzed during and after data collection period based on example of Lytle and Hutchinson (2004), who used phenomenological process (Denzin \& Lincoln, 2000; Strauss \& Corbin, 1990). Phenomenological theory focuses on how people experience, describe, and make meaning for things through their senses. The process of data analysis can be briefly described in following steps:

(a) Reduction of data: locate personal experiences that address the phenomena in question (nature of APE specialist); interpret the meaning of these beliefs; obtain interpretation of the beliefs by participants; inspect these meanings.

(b) Organization of data into meaningful clusters.

(c) Delimitation of data by irrelevant, repetitive or overlapping data.

(d) Grouping of statements into meaningful units.

(e) Extracting meanings by developing textual description.

(f) Synthesis of resulting context with the current literature (Patton, 2002).

\section{RESULTS}

The nature of work of public school adapted physical educators

Typical Workday of Adapted Physical Education Specialist:

The one participant claimed that there is no typical workday in adapted physical education. In a sense that appears to be truth. Only common thing is time schedule. Usually teacher start their day around eight o'clock and go till about 3:30 or 4:00. In one case teacher claimed that she does not get out of work till 5:30 on two days of the week. Apart from one participant, teachers taught at more then four school. Therefore they had to spend lot of time traveling from school to school. It appeared that most of teachers have some sort of schedule, which usually consists of two rotations a week, for example Mondays,
Wednesdays and Fridays same schedule and Tuesdays and Thursdays same schedule.

One teacher claimed: ... in my school district I do preschool through high school and to keep my sanity I schedule Tuesdays and Thursdays the same and Mondays and Wednesdays the same." On the other hand one teacher claimed that her schedule changes constantly. "It changes so much, it is hard to keep it all in my head."

Teachers have classes lasting from 30 minutes to 45 minutes. They also have time allotted for paperwork, but some of them have little or no time and place to eat lunch. One teacher was also involved in teaching handwriting skills.

\section{The Appropriateness of the Adapted Physical Education Caseload}

Most participants thought that their caseload was appropriate. As we can see from table one, most of our teachers had caseload from 44 to 60 students. Two teachers, who had caseload of 90 students reflected major problems with the size of their caseload.

My caseload is ridiculous. It is absurd to have 90 kids to be in charge of per week... I do not think that is what this profession needs. People do not take us seriously, because of what they see us doing. I look like a clown, I look frantic. I have all this equipment, I throw it down, I do these things, kids are having fun... and I have to go. Our caseload is pretty absurd, ninety kids....no.

In one large school district with 175 APE teachers, the teachers are assigned to the number of school that they serve. Therefore caseload is not being the determinant of number of students being served. The problem might be with the required paperwork, attendance of IEP meetings or extra assessment duties. "The problem is we are being asked and requested to attend IEP meetings, and to do our paperwork and write IEPs and to test and we do not have an appropriate amount of time to do all those things required." 
The roles of work of public school adapted physical educators

Consulting General Physical Education Teachers Most participants reported both positive and negative experiences with general physical education teachers. It appeared that with longer teaching experience, the working relationship between PE teachers and APE specialists improved.

...After almost 20 years doing it in ...., they are receptive and they are aware of $i$. Each year I see it as progression,...next year and the next year, it just kept getting better and better.

...I am getting better at it, or I am getting report with my coaches. I think some of them feel threatened, when I come in there or kind of overwhelmed or they rely on me to do everything for them.

There appears to be difference between elementary PE teachers and middle, high school teachers with elementary PE teachers being more receptive to inclusion of students with disabilities.

...Fortunately we have 14 elementary PE specialists and they are awesome. .. The middle and high school is much harder. You have the good old boys, who usually are the athletic people, who teach athletics and not physical education.

Some teachers ask for consulting services, mainly in the areas of safety and activity modification. Caring professionals can make huge differences in the lives of children. One participant claimed that paraprofessional were often more interested in consultation that PE teachers. Bad experience is unfortunately common as well. Some PE teachers do not believe that they should be teaching students with disabilities.

Some of the teachers can be very assertive about their position as one participant shared:

...she just turned around and yelled at me, telling me I am not credentialed, this is unsafe, I am going to the union, I mean hundred and one ways why not to do this (inclusion of student with disability into general PE class).
It appeared that teacher's negative attitude towards teaching students with disabilities goes on to the other students in class. In such occasions, students without disabilities referred to APE teacher as "your teacher is here".

It also appears to be crucial to be able to work with students' awareness about special needs of students with disabilities. Students can play important roles (Klavina \& Block, 2008) in facilitating inclusion and well prepared class is the best step toward successful inclusion in physical education.

...you know the children have questions about students with disabilities and if you do not ask those questions, and then there is a fear.

In conclusion there are many good examples of consultation of general physical educators (cooperation between APE and PE specialists). This relationship seems to be dependent on trust and cooperation over the extended period of time.

\section{The Role in Decision Making - IEP meetings}

In contrary with Kelly and Gensender (1998) all of our participants reported being involved in most of the decision making process. Our results must be interpreted with caution, because of limited sample size and purposive sampling technique. All participants of our study assessed students and they were also responsible for suggestions of service and placement for particular students. In their decision making process they cooperated with PE teachers, classroom teachers and parents of students with disabilities.

In our schools, we are considered experts and we usually have the say in what this child is going to get.

Most of the decisions are done in IEP meeting (meetings where the team of experts discusses the needs of each child with special needs and determines his/her goals for given academic year), which usually accepts the recommendations of APE specialists. However it is often being suggested or required that $\mathrm{APE}$ 
specialists attend IEP meetings. There appeared to be conflict in being involved in IEP meetings, while not canceling any teaching duties. The policy about attending IEP meetings seems to be very different in different school districts. The least amount of attended meetings was reported by teacher, in whose district it is never requested and parents usually do not question suggested placement. On the other hand, they communicate with parents before the IEP meeting and if necessary they have pre IEP meeting with focus on APE. The other extreme was 120 IEP meetings that were required for one specialist with huge caseload of 90 students. There seemed to be major conflict between attending IEP meetings and canceling classes.

In one school district IEP meetings were scheduled for after school time, and this became an issue with Teachers Union.

So IEP meetings should be done in school hours, but I will refuse to cancel my class, because of IEP meeting. I attend only very, very important ones.

Another participant also expressed concern with scheduling IEP meeting during the school hours.

I attended probably 60 IEP meetings in my regular teaching day...not good...not good.

\section{Biggest Challenges in APA in the School District}

Things that participants would like to change were clustered into following areas: (a) administrative support and respect, (b) appropriateness of caseload and increase of service time, (c) time for training and staff development, and (d) place to teach. Many participants mentioned support and respect of administrators as well as general education personnel.

...We are not playground leaders, we have credentials and we know what we are doing.

...I would like to change administration and how they look at us.

Some problems might be solved if there would be the adapted physical education coordinator, who would oversee administrative part of adapted PE.

Another issue was to improve the appropriateness of caseload. As discussed in previous findings, caseload plays critical role in quality of the program.

Hire more, so we can see students.

One teacher also suggested lowering the amount of paperwork, so more instructional time can be devoted to working with the children. More time for staff training and development was suggested by two participants. Other things that participants would like to change are: more parental involvement, access to adapted equipment, more inclusion and working in motor team to maximize students' potentials.

\section{Reflection in Adapted Physical Education Teacher Training Programs}

Things that our participants would like to change in pre service preparation were clustered into the areas of: (a) practicum experience with people with disabilities, (b) consultation and people skills, (c) assessment and IEP, preparing students for "real life" teaching and (e) modifications of activities. Practically all participants stressed the importance of hands on experiences with people with disabilities. They claimed that it is important to get experience with students with various disabilities across the whole life-span. Another major cluster of perceived needs was the areas of consultation. ...learn people skills. Learn how to talk to people, how to relate to people, how not to be intimidated, how to be cooperative....

...communication between a school and the special education team....preparation for the interaction with regular PE teachers.

Participants also put emphasis into the preparation for "real life teaching": (a) what does it really mean to be itinerate (teacher) and how do you manage a day, when no day is really the same; (b) what are everyday demands of APE specialists. Participants wanted better preparation in the area of assessment and IEP preparation 
with underlying neurological foundation and the knowledge of the law.

Finally there was also the need for better preparation in areas of adaptations.

....Knowing how to take the lesson and maybe modify, break it down...How to take this lesson and make it meaningful for one student, but also for all students so they do not get bored.

\section{DISCUSSION}

There is not such a thing as a typical day of adapted physical education teacher. Usually there is some sort of rotation. The issues involved in this are the lack of teaching place, too much administrative work (paperwork, IEP meetings etc) and transition from site to site. Kelly and Gansender (1998) stated that mean time of traveling between the schools was 5.5 hours per week. The caseload size and administrative responsibilities clearly shape the professional days of APE teachers. Observed caseload was 44 to 60 students. Most of the participants suggested that the appropriate caseload is about 55 students. California Department of Education (1993) pointed out several factors that might influence the appropriateness of caseload: (a) number of classes and contact hours, (b) number of days per week each child receives services, (c) travel time and distance between sites, (d) working conditions, (e) availability of support services, (f) severity of disability etc. Thus, we see that the caseload count is not the only measure of the appropriateness of the number of served students.

All of the participants were involved in different roles in consulting as described in Lytle and Hutchinson (2004). They had both positive and negative experiences. Positive experiences seemed to be related to the relationship over the extended period of time. Most negative experiences seemed to be caused by negative attitudes and teaching philosophy of $\mathrm{PE}$ specialists. In those cases PE teachers are most likely not to request consulting. If such teacher is referred to consulting by other specialists, he/she usually does not trust consultant and often does not perceive that there is a problem (Block \& Conaster, 1999). There seems to be hope, because many APE specialists reported the improvement of relationship between APE and PE specialist with the time of cooperation.

Areas that APE teachers would like to improve are directly related to the above questioned areas. In summary teachers would like to gain more respect and understanding, more time for staff development and consistent place to teach. As far as professional preparation goes, participants emphasized the preparation for "real life" teaching and practicum experiences with people with various disabilities across the life span. The other two areas were the assessment and adaptation of sports and activities. High emphasis on consultation seems to be in contrary to finding of Kelly and Gansender (1998), who find consultation to be on the bottom of emphasized areas.

\section{CONCLUSION}

Currently the job description of adapted physical education specialists is very limited. There is still great need to further explore the nature of work of APE specialists worldwide in both direct teaching and indirect consulting positions. There are many issues that need to be studied (e.g. the appropriateness of caseload, the roles and responsibilities of APE teachers in a school district). There is still a need for the advocacy for adapted physical education with emphasis on the importance of APE service for students with disabilities. There appears to be need for more appropriate teaching place for APE and more equipment. All of the perceived problems seem to be related to the lack of importance that APE has among the educational services. The job description of APE teachers is very open and flexible. Therefore here is a description of one participant that seems to fit our needs. 
You have many hats and many roles. Number one thing is, we work with lot of different attitudes, of teachers, aides, staff. There is a huge equipment issue. You are teaching and everything you carry is inside your car, including your radio, teaching materials and your office is in your car. It gets really old after 15 years. I used to set up at 12 schools every day, in and out of my car, that is a lot of set ups. At the beginning of the year I make sure I have teaching place to be, I even got really close with custodians and maintenance, and the warehouse people. So I leave equipment in closets in each school so I can just set up from there instead of moving it in and out of my car. I got a ticket once for parking in the red zone. These are lot of dynamics that you have to think about and in each school I like to set myself up. Because we do the elementary PE specialists, they are letting me use their equipment. We have lot of assistive devices and I used to that all out of my truck. My truck got stolen, so now I have to call the warehouse. Important is to have good working relationship, I always tell then thank you. I always send them, would you please do this and send them a little candy and little note. I always gave all my teachers warm fuzzies all the time, sending memos, sending pencils. I found what sport they were interested in and found a pen or pencil with golf ball on it or something. I still do that it is important and then they will help you out again.

\section{ACKNOWLEDGMENT}

The study was supported by the research grant from the Ministry of Education, Youth and Sports of the Czech Republic (No. MSM 6198959221) ,Physical Activity and Inactivity of the Inhabitants of the Czech Republic in the Context of Behavioral Changes".

\section{REFERENCE}

Anastas, J.W., \& MacDonald, M.L. (1994). Research design for social work and the human services. New York: Lexington Books.
Block, M.E. (1994). A teacher's guide to including students with disabilities in regular physical education. Baltimore: Paul H. Brookes.

Block, M. E., \& Conaster, P. (1999). Consulting in adapted physical education. Adapted Physical Activity Quarterly, 16, 9-26.

Block, M.E., \& Obrusníková, I. (2007). Inclusion in physical education: A Review of the literature from 1995-2005. Adapted Physical Activity Quarterly, 24, 103-124.

California Department of Education. (1993). Program advisory clarifying adapted physical education program services. Sacramento, CA: Author.

Denzin, N.K., \& Lincoln, Y.S. (2000). Handbook of Qualitative Research (2 ${ }^{\text {nd }}$ ed.). Thousand Oaks, CA: Sage Publication.

Heikinaro-Johanson, P., Sherrill, C., French, R., \& Huuhka, H. (1995) Adapted physical education consultant service model to facilitate inclusion. Adapted Physical Activity Quarterly, 12, 12-33.

Kelly, L.K., \& Gansender, B. (1998). Preparation and job demographics of adapted physical educators in the United States. Adapted Physical Activity Quarterly, 15, 141-154.

Klavina, A. \& Block, M. (2008). The effect of peer tutoring on interaction behaviors in inclusive physical education. Adapted Physical Activity Quarterly, 25, 132-158.

Kudláček, M., Válková, H., Sherrill, C., Myers, B., \& French, R. (2002). An inclusion instrument based on planned behavior theory for prospective Czech physical educators. Adapted Physical Activity Quarterly, 19, 280299.

LaMaster, K., Gall, K., Kinchin, G., \& Siedentop, D. (1998). Inclusion practices of effective elementary specialists. Adapted Physical Activity Quarterly, 15, 64-81.

Lieberman, L.J., Houston-Wilson, C., \& Kozub, F.M. (2002). Perceived barriers to including students with visual impairments in general physical education. Adapted Physical Activity Quarterly, 19, 364-377. 
Lienert C., Sherrill, C., \& Myers, B. (2001). Physical educators' concerns about integrating children with disabilities: A cross-cultural comparison. Adapted Physical Activity Quarterly, 18(1), 1-17.

Lytle, R.K., \& Hutchinson, G.E. (2004). Adapted physical educators: The multiple roles of consultants. Adapted Physical Activity Quarterly, 21, 34-49.

Meegean, S., \& MacPhail, A. (2006). Irish physical educators attitude toward teaching students with special educational needs. European Physical Education Review, 12(1), 75-97.

Morley, D., Bailey, R., Tan, J., \& Cooke, B. (2005). Inclusive physical education: teachers views of including pupils with special educational needs and/or disabilities in physical education. European Physical Education Review, 11(1), 84-107.
Patton, M. (2002). Qualitative Research and Evaluation Methods ( ${ }^{\text {rd }}$ ed.). Thousand Oaks, CA: Sage Publications.

Sherrill, C. (1998). Adapted physical activity, recreation and sport (5th ed.) Madison, WI: WCB/McGraw Hill.

Sherrill, C., \& O'Connor, J. (1999). Guidelines for improving adapted physical activity research. Adapted Physical Activity Quarterly, $16,1-8$.

Strauss, A., \& Corbin, J. (1990). Basics of qualitative research: Grounded theory procedures and techniques. Newbury Park, CA: Sage Publications.

Corresponding author's e-mail address: martin.kudlacek@upol.cz

\section{ARBEITSPROFIL UND ROLLE VON BEHINDERTENSPORTLEHRENDEN IN ÖFFENTLICHEN SCHULEN IN DEN VEREINIGTEN STAATEN}

(Resümee)

Die Absicht dieser Studie war die Beschreibung des Arbeitsprofils und der Rolle von Behindertensportlehrenden (Adapted Physical Educators) in ausgewählten Schulbezirken der Vereinigten Staaten. Von größter Bedeutung war dabei die Schaffung einer Informationsbasis zur Steuerung der Verbesserung des Unterrichts und der beruflichen Ausbildung. Die Teilnehmer/innen waren 6 Frauen und 2 Männer mit 2-23 Jahren Lehrerfahrung auf dem Gebiet von Bewegungserziehung im Behindertensport (Adapted Physical Education - APE). Die Datenerhebung umfasste individuelle Tiefeninterviews, demografische Datenblätter und Interview-Aufzeichnungen. Die Ergebnisse zeigten die Unterschiede im Arbeitsprofil der APE Spezialist/innen. Die Teilnehmenden hatten eine hohe Lehrbelastung (44-90 Schüler/innen) und arbeiteten in mehreren verschiedenen Schulen (1-20), was daher ziemlich unterschiedliche Lehrprofile ergab. Die meisten Lehrenden waren auch in APE-Beratung involviert. Die Ergebnisse zeigten auch das Bedürfnis auf, Themen der Beratung in die Lehrerausbildung aufzunehmen und die Universitätsstudien mehr an ein „Lehren im realen Leben“ anzupassen.

SCHLÜSSELWÖRTER: Sportunterricht, Inklusion, Adapted Physical Educators, Arbeit 


\section{LA NATURE DU TRAVAIL ET LES ROLES DES EDUCATEURS EN EDUCATION PHYSIQUE ADAPTEE DANS LES ECOLES PUBLIQUES AUX ETATS-UNIS}

(Résumé)

Les but de cette étude est de décrire la nature du travail et les rôles des éducateurs en éducation physique adaptée dans les écoles publiques de quartiers sélectionnés aux Etats-Unis. La portée la plus importante de cette recherche est la création d'une base d'informations pour améliorer les prestations de service et la préparation professionnelle. 6 femmes et 2 hommes (écart d'âge de 2-23 ans) ayant une expérience d'enseignement antérieure dans le champ de l'Education Physique Adaptée (EPA) participent à cette étude. La collection de données inclut des entretiens individuels, des données démographiques et des notes d'entretiens. Les résultats montrent des différences dans la nature du travail des spécialistes en EPA. Les participants ont une charge importante d'enseignement (44-90 élèves) et travaillent dans une large gamme d'établissements (1-20). Cela crée des profils d'enseignants assez différents. La plupart des professeurs s'investissent dans des enquêtes en EPA. Les résultats indiquent également la nécessité d'intégrer les résultats des enquêtes dans la préparation des professeurs et de changer les études universitaires pour les rendre plus représentatives des «vies professionnelles réelles ».

MOTS CLEFS : Education Physique, Inclusion, Educateurs en Education Physique Adaptée, Travail. 